\title{
Military Officer Special and Tactical Operations Leaders and Managers
}

National Cancer Institute

\section{Source}

National Cancer Institute. Military Officer Special and Tactical Operations Leaders and

Managers. NCl Thesaurus. Code C122484.

The group of professions that include air crew officers, aircraft launch and recovery

officers, armored assault vehicle officers, artillery and missile officers, command and control center officers, infantry officers, and special forces officers. 